\title{
JEKK
}

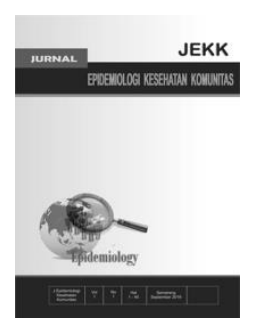

\section{Profil Fitokomponen dan Aktivitas Ekstrak Metanol Daun Intaran Bali (Azadiractha Indica Juss.) Terhadap Candida albicans ATCC-10231}

\author{
Meylana Ayu Melinda*, Agung Nova Mahendra** \\ "Program Studi Farmasi, FMIPA, Universitas Udayana, Denpasar-Bali, Indonesia \\ ** Departemen Farmakologi dan Terapi, Fakultas Kedokteran, Universitas Udayana, Denpasar-Bali, Indonesia
}

\begin{abstract}
Background: Candidiasis, usually caused by Candida albicans is commonly found in clinical settings. Resistance of $C$. albicans against antifungals is an emerging issue. This study was aimed to determine the selected quantitative phytocomponent profile and evaluate the effectiveness of intaran (Azadiractha indica A. Juss) leaf extract from Bali in inhibiting the growth of C. albicans .

Methods: This experimental research was conducted at the Center for Marine Aquaculture Research and Development (Buleleng, Bali), Laboratory Service Unit, Faculty of Agricultural Technology, Udayana University, and Microbiology Laboratory, Department of Biology, Faculty of Mathematics and Natural Sciences, Udayana University, Denpasar, Bali. Our study included the preparation of the methanol extract of intaran leaves using maceration method, phytochemical analysis, and testing the antifungal activity of the extract using the diffusion disk assay against $C$. albicans ATCC-10231.

Results: Phytochemical components in the methanol extract of intaran Bali leaves were chlorophyll (18434.47 mg/L), total antioxidants (4818.07 $\mathrm{mg} / \mathrm{L}$ GAEAC), phenol (4391.16 $\mathrm{mg} / 100 \mathrm{gr} \mathrm{GAE})$ and flavonoids (785.32 mg/100gr QE). The extract exhibited dose-dependent effect, with greatest inhibition against $C$. albicans ATCC-10231 growth was obtained at the concentration of $50 \%$.

Conclusion: Methanol extract of Balinese intaran leaves contained significant amount of chlorophyll, total antioxidants, phenol, and flavonoids. The extract showed antifungal activity against C. albicans ATCC-10231. This anticandidal effect is assumed to be related to the phytocomponents of the extract.
\end{abstract}

Keywords: Azadiractha indica A. Juss; leaf extract; phytocomponents; antifungal activity; Candida albicans ATCC-10231

*Penulis korespondensi, novamahendra@unud.ac.id 


\section{Pendahuluan}

Berbagai penyakit yang diakibatkan oleh infeksi jamur tidak jarang ditemukan di setting klinis. Penyakit ini perlu mendapat perhatian yang lebih serius karena seringkali mematikan dan menyebabkan kematian hingga lebih dari 1,5 juta jiwa setahun dan jumlah kasus yang lebih dari 1 triliun setahun. ${ }^{1}$ Kasus-kasus infeksi jamur yang berat seringkali muncul karena berbagai kondisi yang menyebabkan imunosupresi. $^{2}$ Salah satu penyakit yang diakibatkan oleh jamur yang sering dihadapi di ranah klinis yaitu kandidiasis yang umumnya disebabkan oleh Candida albicans. Resistensi C. albicans terhadap berbagai golongan obat antijamur merupakan salah satu isu yang bersifat emerging di bidang kesehatan, dengan berbagai mekanisme yang telah dikaji secara komprehensif oleh. ${ }^{3}$ Oleh karena itu, perlu dilakukan pengkajian terhadap bahan-bahan alternatif yang bersumber dari alam sebagai sumber obat antijamur yang baru untuk membantu mengatasi hal ini.

Flavonoid merupakan salah satu kelompok senyawa alami yang berpotensi dikembangkan sebagai antijamur. Flavonoid dapat menghambat germinasi spora jamur fitopatogen tanaman, oleh karena itu maka bahan alam yang kaya flavonoid diduga memiliki potensi untuk dikembangkan terhadap jamur patogen pada manusia. ${ }^{4}$ Indonesia sebagai negara dengan mega-biodiversitas merupakan "ladang emas" sumber bahan alam kaya flavonoid, terutama yang bersumber dari tumbuhan. Masyarakat setempat umumnya mengambil manfaat dari tumbuhan untuk menggantikan obat modern dalam menjaga kesehatan dan mengobati penyakit berdasarkan pengetahuan empiris. ${ }^{5}$

Salah satu tanaman yang kaya flavonoid dan bernilai terapeutik yang banyak digali manfaatnya di dunia yaitu Azadirachta indica A. Juss. Tanaman ini tercatat sebagai tanaman pertama yang disebut dalam Siddha (Siddha medicine). Siddha adalah suatu sistem pengobatan berusia ribuan tahun yang bersumber dari India Selatan, yang sampai saat ini masih diterapkan di India, Sri Lanka dan beberapa negara di Asia Tenggara. ${ }^{6}$ Berbagai khasiat Azadirachta indica A. Juss. yang tumbuh di berbagai negara atau area di luar Bali telah diteliti, dan telah dibuktikan berbagai aktivitas farmakologiknya, baik secara in vivo maupun secara klinis. Sejauh ini, penelitian terhadap kandungan fitokimia dan khasiat dari daun intaran yang bersumber dari Bali terhadap jamur dari genus Candida belum pernah dikaji. Berdasarkan latar belakang yang telah ditunjukkan, penting dilakukan kajian terhadap profil fitokomponen dan efek daun intaran Bali sebagai antijamur, khususnya terhadap C. albicans. Sebagai langkah awal, maka dilakukan profiling terhadap fitokomponen ekstrak daun intaran Bali, kemudian dilakukan pengujian efek inhibisi ekstrak terhadap C. albicans isolat non-klinis, yaitu C. albicans ATCC-10231.

\section{Metode}

Daun intaran diambil dari pohon intaran yang tumbuh di areal Universitas Udayana, Bukit Jimbaran, Kabupaten Badung, Bali. Berat daun yang diambil adalah 300 gram. Daun ini selanjutnya dicuci dengan air lalu dianginkan. Kemudian dilakukan pengeringan menggunakan metode freeze drying di Balai Besar Penelitian dan Pengembangan Budidaya Laut, Desa Gondol, Kecamatan Grokgak, Buleleng. Berat daun yang diperoleh setelah pengeringan adalah 146 gram. Daun kering selanjutnya diblender hingga menjadi serbuk. Berat serbuk yang digunakan adalah 100 gram.

Sebanyak 100 gram serbuk daun intaran dimaserasi dalam $1000 \mathrm{~mL}$ metanol. Maserasi dilakukan selama 24 jam. Hasil maserasi selama 24 jam tersebut dikeringkan dengan cara penyaringan untuk memperoleh filtrat daun intaran. Selanjutnya dilakukan evaporasi terhadap larutan metanol daun intaran. Evaporasi dilakukan dengan menggunakan rotary evaporator selama 8 jam. Hasil yang didapat yaitu ekstrak metanol daun intaran sebanyak 10 gram.

Ekstrak daun intaran yang diperoleh dari evaporasi selanjutnya diuji untuk didapat profil kuantitatif dari beberapa senyawa aktifnya. Analisis komponen bioaktif dilakukan di Laboratorium Farmakologi dan Terapi Fakultas Kedokteran Universitas Udayana . 
Ekstrak daun intaran yang diperoleh selanjutnya diujikan pada $C$. albicans ATCC10231 menggunakan media SDA. Ekstrak diteteskan pada media SDA yang sudah diberi C. albicans dengan konsentrasi 25\%, 50\%, $75 \%$, 95\% dalam satu disk dan diamati pertumbuhannya.

\section{Hasil}

Tabel 1. Profil Kuantitatif Senyawa Terpilih Ekstrak Metanol Daun Intaran (Azadiractha indica A. Juss).

\begin{tabular}{lcccc}
\hline $\begin{array}{l}\text { Sam- } \\
\text { pel }\end{array}$ & $\begin{array}{c}\text { Flavono- } \\
\text { id } \\
(\mathbf{m g / 1 0 0 g r} \\
\text { QE) }\end{array}$ & $\begin{array}{c}\text { Fenol } \\
(\mathbf{m g} / \mathbf{1 0 0 g r} \\
\text { GAE })\end{array}$ & $\begin{array}{c}\text { Antioksi } \\
\text {-dan } \\
(\mathbf{m g} / \mathbf{L} \\
\text { GAEAC) }\end{array}$ & $\begin{array}{c}\text { Total } \\
\text { Klorofil } \\
(\mathbf{m g} / \mathbf{L})\end{array}$ \\
\hline $\begin{array}{l}\text { Daun } \\
\text { Intaran }\end{array}$ & 785,32 & 4391,16 & 4818,07 & 18434,47 \\
\hline
\end{tabular}

Analisis fitokimia terhadap ekstrak metanol daun intaran kemudian dilanjutkan dengan uji inhibisi terhadap pertumbuhan $\mathrm{C}$. albicans secara in vitro. Hasil uji inhibisi ini dapat dilihat pada gambar 1 dan 2 , serta tabel 2 .

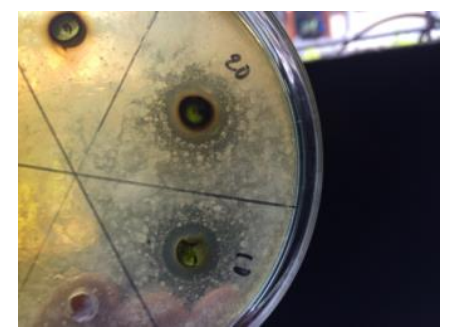

Gambar 1. Diameter zona hambat ekstrak daun intaran terhadap C. albicans.

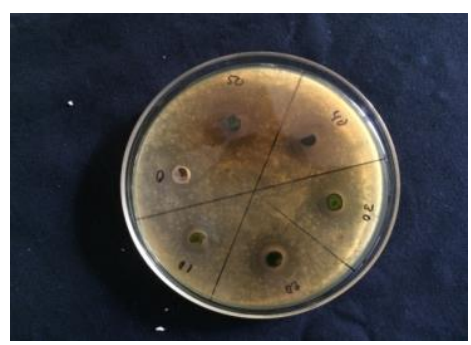

Gambar 2. Diameter zona hambat ekstrak daun intaran terhadap C. albicans.
Tabel 2. Hasil pengukuran zona hambat ekstrak daun intaran terhadap C. albicans.

\begin{tabular}{cl}
\hline Konsentrasi (\%) & $\begin{array}{c}\text { Diameter Zone } \\
\text { Hambatan (mm) }\end{array}$ \\
\cline { 2 - 2 } & \multicolumn{1}{c}{ Candida albicans } \\
\hline $\mathbf{0}$ & 0 \\
$\mathbf{1 0}$ & 11 \\
$\mathbf{2 0}$ & 13 \\
$\mathbf{3 0}$ & 15 \\
$\mathbf{4 0}$ & 17 \\
$\mathbf{5 0}$ & 18 \\
\hline
\end{tabular}

\section{Pembahasan}

Penelitian ini dilakukan untuk menginvestigasi dua hal utama, yaitu kadar fitokomponen terpilih serta aktivitas inhibisi ekstrak metanol daun intaran Bali terhadap $C$. albicans. Dari penelitian yang telah dilakukan diperoleh hasil berupa senyawa aktif yaitu klorofil, antioksidan total, fenol, dan flavonoid. Klorofil menunjukkan aktivitas antijamur, baik terhadap C. albicans (isolat klinis dan ATCC), maupun spesies non-albicans dari isolat klinis yang dapat menyebabkan mukositis berat. Klorofil yang bersumber dari ekstrak air Spirullina platensis, pada dosis yang efektif terhadap berbagai galur Candida spp., ditemukan memiliki profil toksisitas in vitro yang baik. Hal ini dapat diketahui dari efeknya yang tidak mempengaruhi kontraktilitas sel otot polos miometrium, bersifat kompatibel terhadap mikroflora normal dari vagina dan tidak bersifat sitotoksik. ${ }^{7}$ Kandungan klorofil yang banyak terkandung pada ekstrak metanol daun intaran sebagai fitokomponen membawa implikasi bahwa ekstrak ini berpotensi dikembangkan menjadi agen antijamur yang efektif dan toksisitas yang minimal. Ada beberapa strategi yang kami ajukan dalam menjawab tantangan ini di masa mendatang. Pertama, kami menekankan perlunya dilakukan kajian terhadap efek samping dari ekstrak metanol daun intaran Bali, khususnya efek miotoksik dan sitotoksik. Kedua, mengingat pentingnya preservasi faktor protektif antikandidiasis yang alami, maka penting pula dilakukan studi terhadap efek disruptif esktrak metanol daun intaran terhadap pertumbuhan Lactobacillus spp. 
Ekstrak metanol daun intaran Bali pada penelitian ini juga ditemukan mengandung 2 kelompok senyawa lain yaitu fenol dan flavonoid. Dua kelompok senyawa ini dikenal sebagai antioksidan alami. ${ }^{8}$ Pernyataan ini didukung juga dengan temuan berupa kemampuan fenol total dalam ekstrak Lumbricus rubellus dari lahan pertanian organik di Bali yang menunjukkan aktivitas antioksidan in vitro. ${ }^{9}$ Senyawa fenolik sebagai antioksidan sangat bergantung pada jenis pelarut, karena senyawa antioksidan memiliki karakteristik kimia dan polaritas yang beragam. Penggunaan pelarut dalam ekstraksi sangat berpengaruh terhadap hasil yang diperoleh. ${ }^{10}$ Dalam penelitian yang dilakukan oleh DieuHien Truong et al. (2019) ${ }^{11}$ terhadap Severinia buxifolia ditemukan bahwa pelarut metanol merupakan pelarut terbaik yang dapat digunakan dalam ekstraksi senyawa aktif dan diketahui bahwa ekstrak metanol sangat menjanjikan dikembangkan sebagai agen antioksidan dan anti-inflamasi untuk industri farmasi. Ekstrak metanol dari daun tumbuhan Cassia fistula dapat dijadikan sebagai pembanding tambahan yang memperkuat temuan dalam studi terhadap daun intaran Bali ini. Pada penelitian yang dilakukan oleh Kadhim et al. (2016) ${ }^{12}$, ekstrak metanol daun Cassia fistula diketahui bahwa ekstrak mengandung fenol dan flavonoid, serta menunjukkan aktivitas anti-Candida. Konsentrasi senyawa fenolik dan flavonoid yang tinggi dari suatu ekstrak metanol berkontribusi penting terhadap aktivitas antioksidan dan anti inflamasi ekstrak tersebut. Berdasarkan kajian literatur, flavonoid diketahui memiliki sejumlah mekanisme kerja sebagai antijamur, yaitu: (1) memicu disintegrasi membran sel jamur, (2) inhibisi sintesis $\beta$-glucans dan chitin, (3) inhibisi rantai transport elektron, (4) inhibisi pembelahan sel, (5) inhibisi aktivitas pompa efflux, (6) inhibisi sintesis asam nukleat dan protein. Berbagai efek ini telah diteliti pada $C$. albicans, spesies non-albicans maupun terhadap jamur patogenik dari genera Aspergillus dan Trichophyton. ${ }^{13}$

Daya hambat yang ditunjukkan oleh ekstrak methanol daun intaran Bali dalam penelitian ini bersifat dose-dependent.
Berdasarkan temuan analisis fitokimia yang didapat, efek antijamur yang ditimbulkan oleh paparan terhadap ekstrak metanol ini diduga terkait dengan adanya klorofil, serta fenol dan flavonoid. Ekstrak metanol daun A. indica dari wilayah semi-arid di Nigeria, dibandingkan dengan ekstrak etil asetat dan ekstrak heksan, menunjukkan aktivitas in vitro yang moderat terhadap $C$. albicans. Secara kualitatif ekstrak daun $A$. indica dari Nigeria, ditemukan mengandung alkaloid (fitokomponen terbanyak; +++$)$ dan fenol $(++)$, namun tidak ditemukan adanya flavonoid. ${ }^{14}$ Dibandingkan dengan studi yang dilakukan oleh Benisheikh et al. (2019) ${ }^{14}$ ini, dari studi yang kami lakukan ditemukan adanya flavonoid dalam ekstrak metanol daun intaran Bali. Hal ini merupakan kelebihan yang potensial untuk dikaji lebih lanjut, mengingat flavonoid merupakan salah satu kelompok senyawa yang dikenal memiliki aktivitas antijamur berspektrum luas dan multitarget. Cara kerja flavonoid yang multitarget ini berpotensi mencegah timbulnya resistensi, sehingga penting untuk kelak dibandingkan resistensi $C$. albicans terhadap komponen bioaktif dari daun intaran versus obat antijamur, seperti misalnya obat dari golongan azol.

Temuan studi in vitro ini menjadi langkah awal bagi pengembangan ekstrak daun intaran Bali sebagai agen baru yang berbasis bahan alam untuk penatalaksanaan kandidiasis. Data profil fitokomponen dari ekstrak metanol daun intaran di Bali dan adanya efek inhibisi terhadap pertumbuhan $C$. albicans in vitro menunjukkan jika bahan alam ini memiliki potensi yang menjanjikan untuk dikembangkan sebagai antikandidiasis. Kajian farmakologis dan tosikologis lanjutan perlu dilakukan agar ekstrak metanol daun intaran Bali sebagai salah satu plasma nutfah bangsa Indonesia dapat dimanfaatkan sebagai agen antijamur baru, setidaknya sebagai agen terapeutik terhadap kandidiasis yang disebabkan oleh $C$. albicans.

\section{Kesimpulan}

Fitokomponen yang terkandung dalam ekstrak metanol daun intaran Bali yaitu klorofil, flavonoid, fenol, dan antioksidan, 
yang diduga berkontribusi bagi inhibisi pertumbuhan $C$. albicans ATCC-10231 in vitro. Efek inhibisi bersifat dose-dependent, dengan daya hambat terbesar diperoleh pada konsentrasi $50 \%$.

\section{Ucapan Terimakasih}

Terimakasih kami sampaikan kepada Ida Ayu Kade Ratna Sukmadewi, S.Si., yang telah membantu pelaksanaan disk-diffusion assay.

\section{Daftar Pustaka}

1. Bongomin, F., Gago, S., Oladele, R., Denning, D. 2017 Global and MultiNational Prevalence of Fungal DiseasesEstimate Precision. J. Fungi. 3: 57.

2. Lu, M.; Li, T.;Wan, J.; Li, X.; Yuan, L.; Sun, S. 2017. Antifungal effects of phytocompounds on Candida species alone and in combination with fluconazole. Int. J. Antimicrobial. Agents. 49: 125-136.

3. Costa-de-Oliveira, S., Rodrigues, A.G. 2020. Candida albicans Antifungal Resistance and Tolerance in Bloodstream Infections: The Triad Yeast-HostAntifungal. Microorganisms. 8 (154): 1-19.

4. Jin, YS. 2019. Recent advances in natural antifungal flavonoids and their derivatives. Bioorganic \& Medicinal Chemistry Letters. 29 (19): 1-13.

5. Hamzah, H., Hertiani, T., Pratiwi, S.U.T., dan Nuryastuti, T., 2020. Inhibitory Activity and Degradation of Curcumin as Anti-Biofilm Polymicrobial on Catheters. International Journal of Research in Pharmaceutical Sciences. 11: 830-835.

6. Kumar, V.S., Navaratnam V. 2013. Neem (Azadirachta indica): Prehistory to contemporary uses to humankind. Asian Pac J Trop Biomed. 3 (7): 505-514

7. Marangoni, A., Foschi, C., Micucci, M., Palomino, R.A.N., Toschi, T.G., Vitali, B. et al. 2017. In vitro activity of Spirulina platensis water extract against different Candida species isolated from vulvovaginal candidiasis cases. PLOS ONE. 12 (11): 1-17.

8. Huyut Z, Beydemir S, Gülçin E. 2017. Antioxidant and Antiradical Properties of Selected Flavonoids and Phenolic Compounds. Biochem Res. Int. 17: 1-10.

9. Sucindra Dewi, Agung Nova, Widi Kencana, Made Jawi, Made Sukrama, dan Ni Luh Kartini. 2017. Ethanolic extract of the powder of red earthworm (Lumbricus rubellus) obtained from several organic farmlands in Bali, Indonesia: Analysis of total phenolic content and antioxidant capacity. Bali Medical Journal. 3 (3): 8083.

10. Salim, E., Afritunando, Y., Febriana, A., dan Mai Efdi. 2019. Studi Optimasi Ekstraksi Kandungan Senyawa Fenolik Total dan Uji Aktivitas Antioksidan dari Daun Manggis (Garcinia mangostana Linn.). Jurnal Riset Kimia. 10 (1): 36-43.

11. Truong, D.H., Nguyen, D.H., Ta, N.T.A., Bui, A.V., Do, T.H., Nguyen H.C. 2019. Evaluation of the Use of Different Solvents for Phytochemical Constituents, Antioxidants, and In vitro AntiInflammatory Activities of Severinia buxifolia. Journal of Food Quality.1-9.

12. Mohanad Jawad Kadhim, Ghaidaa Jihadi Mohammed and Imad Hadi Hameed. 2016. In vitro Antibacterial, Antifungal and Phytochemical Analysis of Metanolic Extract of Fruit Cassia fistula. Oriental Journal Of Chemistry. 32 (3): 1329-1346.

13. Al Aboody, M.S., Mickymarray, S. 2020. Anti-Fungal Efficacy and Mechanisms of Flavonoids. Antibiotics. 9 (45): 1-42. 
14. Benisheikh AAG, Muhammad FM, Kelluri H, Aliyu ZM, Mallam UB, Jibrin MW. 2019. Phytochemical Extraction and Antimicrobial Studies on Crude Leaf Extract of Azadirachta indica (Neem) in Semi-Arid Region of Borno State, Nigeria. International Journal of Research and Review. 6 (12): 516-522. 